\title{
Mixotrophic Denitrification Desulfurization Wastewater Treatment Process: Bioreactor Performance and Analysis of the Microbial Community
}

\author{
Wei Li*, Jianguo Lin, Libo Zhang, Kunpeng Zhu, Xinyi Liu, \\ Zhen Wang, Binxia Cao, Ping Guo \\ College of Environmental Science and Engineering, Dalian Maritime University, \\ No. 1 Linghai Road, Dalian, China, 116026
}

Received: 13 May 2016

Accepted: 21 May 2016

\begin{abstract}
The mixotrophic denitrification desulfurization process was adopted in an upflow attached-growth bioreactor for wastewater treatment. The microorganisms in the system were acclimated to remove sulfide, nitrate, nitrite, and organics simultaneously while the contaminants were finally converted to element sulfur, nitrogen gas, and carbon dioxide. The 16S rDNA clone library technique was utilized to investigate the characteristics of the microbial community within this mixotrophic environment. The results showed that Azoarcus was the main sulfur-based denitrification desulfurization bacteria and had a relative abundance of $8.0 \%$ in this system. It used sulfide as electron donors, with both nitrate and nitrite as eletron acceptors. Thauera, Vulcanibacillus, and Paracoccus were the main heterotrophic denitrification bacteria and had the relative abundances of $29.5 \%, 9.82 \%$, and $1.78 \%$, respectively. They utilized arganics as electron donors, with nitrate or nitrite as electron acceptors. The high removal efficiencies of contaminants were attributed to the interaction of these two main species.
\end{abstract}

Keywords: microbial community, mixotrophic, sulfide, sulfur, nitrite

\section{Introduction}

The wastewater from chemical plants, fermentation factories, paper mills, and pharmacy industries contained high concentrations of ammonia/ammonium $\left(\mathrm{NH}_{3} / \mathrm{NH}_{4}^{+}\right)$ and sulfate $\left(\mathrm{SO}_{4}^{2-}\right)[1]$, which would pollute natural water bodies if discharged directly without proper treatment

*e-mail: weiwei99231@dlmu.edu.cn
[2]. The anaerobic treatment method was the common process for $\mathrm{SO}_{4}^{2-}$ removal, in which $\mathrm{SO}_{4}^{2-}$ was reduced to hydrogen sulfide $\left(\mathrm{H}_{2} \mathrm{~S}\right)$ by sulfate reducing bacteria (SRB) under anaerobic environments [3]. However, $\mathrm{H}_{2} \mathrm{~S}$ was soluble in water and could easily enter the cells of aquatic organisms, which reduced the intracellular redox potential, inactivated the enzyme, and seriously affected the growth metabolism of organisms. It could also cause air pollution if discharged into the atmosphere [4]. And $\mathrm{NH}_{3} / \mathrm{NH}_{4}^{+}$contributed mainly to eutrophication of 
water bodies [5]. In addition, nitrate $\left(\mathrm{NO}_{3}^{-}\right)$, which was the product of the oxidation of $\mathrm{NH}_{3} / \mathrm{NH}_{4}^{+}$, would cause human methemoglobinemia if entering the human body [6]. Meanwhile, $\mathrm{NO}_{3}^{-}$could be reduced to nitrite $\left(\mathrm{NO}_{2}^{-}\right)$ under anaerobic conditions. These nitrogen compounds had risks associated with toxicity and bad odors [7]. Therefore, an integrated wastewater treatment process was highly demanded for the simultaneous removal of nitrogenous and sulfurous compounds.

Last century, Driscol et al. proposed a biological denitrification process using sulfide $\left(\mathrm{S}^{2-}\right)$ as an electron donor [8], and some microorganisms were found to use $\mathrm{NO}_{3}^{-}$as electron acceptors to oxidize $\mathrm{S}^{2-}$ to elemental sulfur (S) [9]. Up to now, the denitrification desulfurization process has been a novel and main method for simultaneous removal of nitrogenous and sulfurous compounds [10-11]. It has been proposed that there might be two main reactions in the denitrification desulfurization process with organic compounds being added to the system [12]: sulfide-based denitrification desulfurization, which used $\mathrm{S}^{2-}$ as the electron donor and $\mathrm{NO}_{3}{ }^{-}$and $\mathrm{NO}_{2}{ }^{-}$as the electron acceptors; and heterotrophic denitrification, which used organics as the electron donors and $\mathrm{NO}_{3}^{-}$and $\mathrm{NO}_{2}^{-}$as the electron acceptors. As this process is based on the metabolism of microorganisms, the exploration of the sulfide-based denitrification desulfurization functional bacteria have recently become the focus of research.

Cai et al. [13] isolated two strains with the function of denitrification desulfurization from the sludges in a long-time running bioreactor treating nitrogenous and sulfurous compounds. Both strains were affiliated with Bacillus and were similar to Bacillus Hemicellulosilytus and Bacillus Halodurans. Chen et al. enriched and screened out 20 strains on selective media [14]. Among these 20 strains, two strains were able to remove more than $60 \%$ of $\mathrm{NO}_{2}{ }^{-}$and $\mathrm{S}^{2-}$. They were facultative anaerobic and mixotrophic heterotrophic, and were similar to Pseudomonas Fluorescens and Pseudomonas Eruginosa. Gevertz et al. isolated two strains of denitrification desulfurization bacteria from the oil fields - both of which were strict chemoautotrophy bacteria [15]. They were similar to Thiomicrospira Denitrifcans and Arcobacter $s p$., respectively. Chen et al. found that the mixed culture (Pseudomonas Fluorescens and Pseudomonas Aeruginosa) could achieve high removal rates of $\mathrm{S}^{2-}, \mathrm{NO}_{2}$, and $\mathrm{NO}_{3}^{-}[16]$.

In a word, the recent studies on denitrification desulfurization were mostly focused on system efficiency and effect factors, such as the ratio of carbon to sulfur, the concentrations of contaminants, and sulfide types [17]. The studies on denitrification desulfurization bacteria focused on the isolation and identification of pure strains. However, because the bacteria leading two types of denitrification both used nitrogenous compounds as electron acceptors and the competitive/collaborative relationship between them was not clear, it was necessary to promote a study on the microbial interaction principles and microbial community characteristics.
In this bioreactor, different kinds of contaminants were removed successfully: $\mathrm{S}^{2-}$ was predominantly oxidized to $\mathrm{S}$, which could be collected for reuse [18]; the organics were further removed by heterotrophic denitrification; and $\mathrm{NO}_{3}{ }^{-}$and $\mathrm{NO}_{2}^{-}$were reduced to nitrogen gas $\left(\mathrm{N}_{2}\right)$ instead of nitous oxide $\left(\mathrm{N}_{2} \mathrm{O}\right)$, which could bring pollution to the atmosphere [19]. The object of this work is to explore the microbial community characteristics in the mixotrophic denitrification desulfurization system, to analyze the competitive/collaborative relationship between different functional bacteria, and to provide microbiological information for improving the treatment efficiency of this process.

\section{Methods and Materials}

\section{Bioreactors and Inoculation}

We used a $3.5 \mathrm{~L}$ anaerobic attached-growth reactor in column shape (Fig. 1). The reactor was inoculated with $1.5 \mathrm{~L}$ of the sludge collected from an anaerobic continuous stirred tank reactor (CSTR) used to treat $\mathrm{NO}_{3}$ and $\mathrm{S}^{2-}$ wastewater, giving the biomass a concentration of $16.5 \mathrm{MLVSSg} / \mathrm{L}$. One peristaltic pump was used to feed artificial wastewater from the bottom of the reactor into the system and the other peristaltic pump was used to recirculate water to achieve uniform mixing. On top of the reactor a three-phase separator was used to separate the biogas, the sludge, and the effluent. Biogas was collected by a water-sealing tank. In order to increase the biomass inside the reactor, sponge cubes $(8 \times 8 \times 8 \mathrm{~mm})$ were applied as attached-growth media, which were washed with distilled water for three times before use. The oxidation-reduction potential (ORP) detector and the $\mathrm{pH}$ detector were inserted into the reactor to test ORP and $\mathrm{pH}$. A constant temperature of $30 \pm 1^{\circ} \mathrm{C}$ inside the reactor was realized via temperature sensor connected with temperature controller (MWZK-02, China) and heating threads bonded around the reactor.

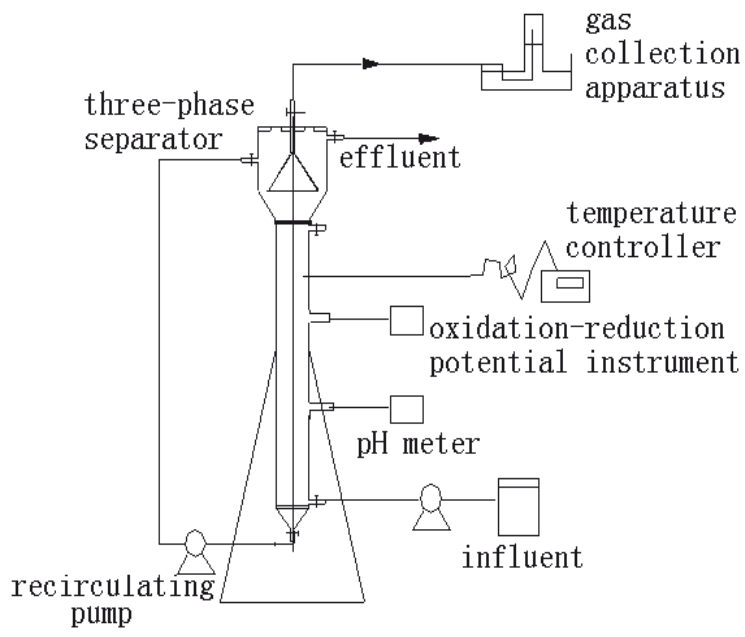

Fig. 1. Schematic view of upflow attached-growth bioreactor. 


\section{Chemical Analytical Methods}

The liquid sample for analyzing was taken from the bioreactor daily. The sulfide was measured using the methylene blue spectrophotometric method (UV-2550, Japan). To measure $\mathrm{SO}_{4}^{2-}, \mathrm{NO}_{3}^{-}$, and $\mathrm{NO}_{2}^{-}$, liquid samples were filtrated with a $0.45 \mu \mathrm{m}$ filter and injected into an ion chromatograph (DIONEX ICS 3000, USA) equipped with an inhibitory type conductivity detector and an Ionpac column (AG4A AS4A-SC, $4 \mathrm{~mm}$ ). The flow rate of carrier liquid was $1.0 \mathrm{~mL} / \mathrm{min} . \mathrm{N}_{2}$ and $\mathrm{N}_{2} \mathrm{O}$ were analyzed by gas chromatography (Agilent 4890D, USA) equipped with a thermal conductivity detector and a molecular screen column $(5 \AA)$. The temperatures of column, injector, and detector were $60^{\circ} \mathrm{C}, 100^{\circ} \mathrm{C}$, and $100^{\circ} \mathrm{C}$, respectively. Measurements for the concentrations of organics (TOC) were taken by a TOC analyzing instrument (TOC-VCPH, Japan). The value of $\mathrm{pH}$ was measured by a $\mathrm{pHs}-3 \mathrm{c}$ $\mathrm{pH}$ meter (China). All the items mentioned above were analyzed according to APHA [20]. Sulfur was analyzed using a method described by Henshaw [21].

\section{Substrates}

Artificial wastewater containing sodium sulfide as electron donor, potassium nitrate and sodium nitrite as electron acceptors, glucose and sodium acetate as organic carbon sources, sodium bicarbonate as an inorganic carbon source, and potassium dihydrogen phosphate as the phosphorus source for bacteria growth were used as the feed to the reactor. The $\mathrm{pH}$ was adjusted to $7.0 \mathrm{using}$ $1 \mathrm{~mol} / \mathrm{L}$ hydrochloric acid. The concentrations of $\mathrm{S}^{2-}$, TOC, $\mathrm{NO}_{3}^{-}$, and $\mathrm{NO}_{2}^{-}$were $389 \mathrm{mgS}^{2-}-\mathrm{S} / \mathrm{L}, 144 \mathrm{mgC} / \mathrm{L}$, $160 \mathrm{mgNO}_{3}^{-}-\mathrm{N} / \mathrm{L}$, and $160 \mathrm{mgNO}_{2}^{-}-\mathrm{N} / \mathrm{L}$, respectively. HRT decreased stepwise from $6.6 \mathrm{~h}, 4.1 \mathrm{~h}$, to $3.3 \mathrm{~h}$, and the influent loadings are shown in Table 1.

\section{Biomass Samples Collection}

For the purpose of microbial community study, biomass was collected directly from the anaerobic system using a tubing system to extract biomass at different points of the bioreactors. The biomass collected was stored in flasks at $-80^{\circ} \mathrm{C}$ until further DNA extraction.

\section{DNA Extraction and PCR Amplification}

Total DNA extraction of the samples was done using the E.Z.N.A. Soil DNA Kit (Omega Biotec, Norcross,
GA, USA, D5625-01) according to the manufacturer's instructions. And the Agarose Gel electrophoresis was done by electrophoresis apparatus (DYCP-31DN, China). The PCR reaction was carried out in a $30 \mu \mathrm{L}$ reaction volume with $15 \mu \mathrm{L}$ Q5 high-fidelity DNA polymerase (New England Biolabs, Ipswich, MA, USA, M0491), $5 \mu \mathrm{L}$ reaction buffer, $5 \mu \mathrm{L}$ high GC buffer, $10 \mathrm{mM}$ dNTP, $10 \mu \mathrm{M}$ forward and reverse primers, and $1 \mu \mathrm{L}$ template DNA. Thermal cycling consisted of denaturation at $98^{\circ} \mathrm{C}$ for 30s, followed by $25-27$ cycles of $98^{\circ} \mathrm{C}$ for $15 \mathrm{~s}, 50^{\circ} \mathrm{C}$ for $30 \mathrm{~s}, 72^{\circ} \mathrm{C}$ for $30 \mathrm{~s}$, and finally $72^{\circ} \mathrm{C}$ for $5 \mathrm{~min}$. The PCR products were analyzed on $2 \%$ agarose gel and purified using a Quant-iT PicoGreen dsDNA Assay Kit (Thermo Fisher Scientific, Waltham, MA, USA, P7589). The results of agarose electrophoresis are shown in Fig. 2.

\section{Clone Library and Sequencing}

The purified PCR products were cloned into $\mathrm{T}$ vector using the pUCm-T Vector Cloning Kit (Sangon Biotech, Shanghai, China, B522213), followed by tranformating competent E. coli cells, selecting positive recombination, and purifying it for further identification using a DNA sequencing analyzer (ABI 3730XL, USA). The sequencing results of bases were compared on EzBioCloud (www.ezbiocloud.net/eztaxon) to obtain the most similar strains.

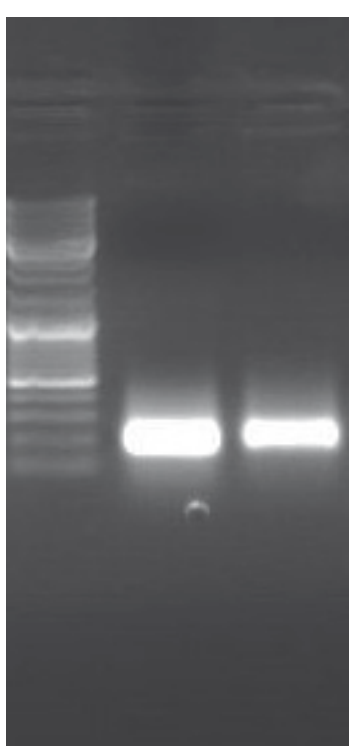

Fig. 2. Agarose gel electrophoretogram of PCR amplification.

Table 1. Influent contaminants.

\begin{tabular}{|c|c|c|c|c|c|}
\hline \multirow{2}{*}{ Day } & Nitrate & Nitrite & Sulfide & TOC & HRT \\
\cline { 2 - 6 } & $\mathrm{mgN} /(\mathrm{L} \cdot \mathrm{d})$ & $\mathrm{mgN} /(\mathrm{L} \cdot \mathrm{d})$ & $\mathrm{mgS} /(\mathrm{L} \cdot \mathrm{d})$ & $\mathrm{mgC} /(\mathrm{L} \cdot \mathrm{d})$ & $\mathrm{h}$ \\
\hline $1-24$ & 579 & 579 & 1,407 & 521 & 6.6 \\
\hline $25-48$ & 928 & 928 & 2,254 & 835 & 4.1 \\
\hline $49-115$ & 1,160 & 1,160 & 2,819 & 1,044 & 3.3 \\
\hline
\end{tabular}




\section{Results}

\section{Simultaneous Removal of Contaminants}

The bioreactor was operated for 115 days. The removal of $\mathrm{S}^{2-}$, TOC, $\mathrm{NO}_{3}^{-}$, and $\mathrm{NO}_{2}^{-}$are shown in Figs 3 and 4. As the inoculation was from a well-sulfide and nitrate-treated anaerobic bioreactor, the removal efficiencies of $\mathrm{S}^{2-}$ and $\mathrm{NO}_{3}^{-}$were high, at above $99 \%$. However, at each start of HRT changing, TOC removal decreased sharply and later increased gradually to a steady value. Nevertheless, this fluctuation weakened gradually with decreasing HRT. And TOC removal efficiency could reach $87.6 \%$ at loading of $1,044 \mathrm{mgC} /(\mathrm{L} \cdot \mathrm{d})$. This performance explained that the microorganisms were affected by influent shock load; but after the microorganisms were adapted to this kind of complicated environment, TOC removal efficiency came to be stable. When HRT was maintained at $6.6 \mathrm{~h}$, $\mathrm{NO}_{2}^{-}$- removal efficiency increased gradually from $75.4 \%$ to $95.2 \%$. At the initial stage, as $\mathrm{NO}_{2}^{-}$might have an inhibition effect on the microorganisms, nitrite removal efficiency was not high. Nevertheless, removal efficiency was enhanced after the microorganisms adapted to the environment.

The high removal efficiencies of contaminants were obtained in the bioreactor, which meant the microorganisms in the bioreactor could remove $\mathrm{S}^{2-}$, $\mathrm{NO}_{3}^{-}, \mathrm{NO}_{2}^{-}$, and organics simultaneously. Therefore, the biofilms were collected from this system for analyzing the microbial community characteristics at this time.

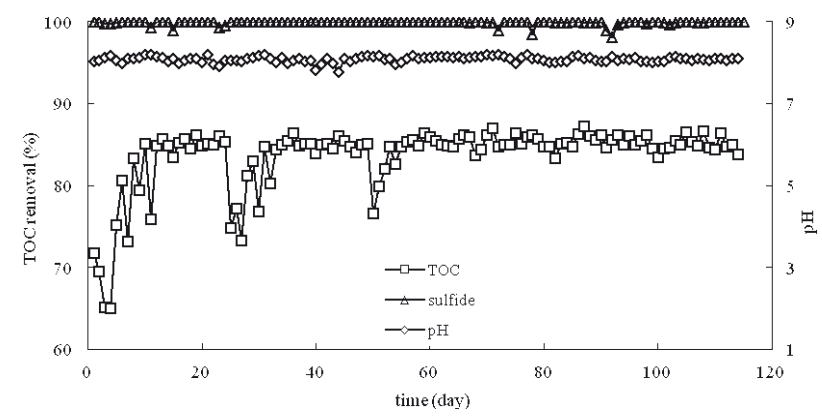

Fig. 3. Removal efficiencies of sulfide and TOC, and $\mathrm{pH}$ variation.

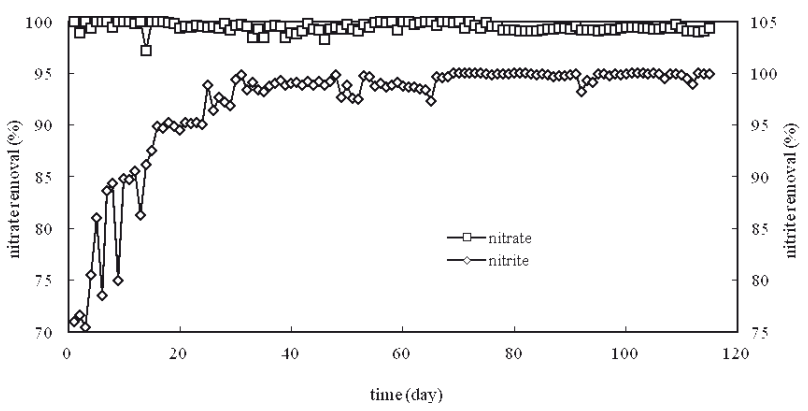

Fig 4. Removal efficiencies of nitrite and nitrate.

\section{Sequencing and Microbial Diversity}

The 112 bands' results of pyrosequencing of $16 \mathrm{~S}$ rDNA gene revealed that this mixotrophic denitrification desulfurization system composed 12 main bacteria that were affiliated with three phyla. The relative abundances were $25.9 \%$ Bacteroidetes, $17.9 \%$ Firmicutes, and $44.6 \%$ Proteobacteria (Table 2).

As the contaminants were removed, the biodiversity not only acclimated but also acted as insurance for denitrification desulfurization system functions against loading changes. The main bacteria for the removal of sulfurous and nitrogenous compounds are listed in Table 3. On the genus level, Thauera, Vulcanibacillus, and Paracoccus were the heterotrphic bacteria for nitrogenous compound removal, whose relative abundances were $29.5 \%, 9.82 \%$, and $1.78 \%$, respectively. Azoarcus was the main simultaneous denitrification desulfurization bacteria in this system, whose relative abundance was $8.0 \%$.

\section{Discussion}

The organics disappeared with sulfurous and nitrogenous compounds in the bioreactor. This simultaneous respiratory process could be explained in terms of the microbial diversity present in this system, where it could be possible to find groups of microorganisms simultaneously carrying out the biological reduction of $\mathrm{NO}_{3}^{-}$and $\mathrm{NO}_{2}{ }^{-}$ using glucose and $\mathrm{S}^{2-}$ as electron donors.

According to Tables 2 and 3, Thauera, Paracoccus, and Vulcanibacillus were the three main species for heterotrophic denitrification in this system. Thauera was in the highest abundance ( 32 bands), which were T.phenylacetica, T.aminoaromatica, T.selenatis, T.m echernichensis, and T.aromatica. Thauera was gramnegative bacteria, in rod shape with flagllum, facultative anaerobic, using $\mathrm{NO}_{3}{ }^{-}$as electron acceptor for denitrification under the anaerobic environment. Its optimum growth temperature was $25-30^{\circ} \mathrm{C}$, and the optimum $\mathrm{pH}$ was 8 . T.phenylacetica was in elliptic or short rod shape, and under anaerobic conditions it could reduce $\mathrm{NO}_{3}^{-}$and $\mathrm{NO}_{2}$ to $\mathrm{N}_{2}$ with no nitrogen fixation [22]. Its optimum growth temperature and $\mathrm{pH}$ were $28^{\circ} \mathrm{C}$ and $7-7.5$, respectively. T.aminoaromatica was in short rod shape. Its optimum growth temperature was $28^{\circ} \mathrm{C}$, while its optimum growth $\mathrm{pH}$ was 7-7.4. It was similar to T.phenylacetica, which could reduce $\mathrm{NO}_{3}^{-}$or $\mathrm{NO}_{2}^{-}$to $\mathrm{N}_{2}$, and had no nitrogen fixation [22]. T.selenatis was found to be able to reduce $\mathrm{NO}_{3}{ }^{-}$to $\mathrm{N}_{2} \mathrm{O}$ by heterotrophic denitrification process [23]. T.aromatica was also found to use organics as carbon sources, and $\mathrm{NO}_{3}^{-}$as an electron acceptor in an anaerobic environment. $\mathrm{NO}_{3}^{-}$was converted to $\mathrm{NO}_{2}{ }^{-}$at first, and then $\mathrm{NO}_{2}{ }_{2}^{-}$was further reduced to $\mathrm{N}_{2} \mathrm{O}$ [24]. However, in this system no $\mathrm{N}_{2} \mathrm{O}$ was detected in the biogas, which might be attributed to the degradation function of T.mechernichensis. Scholten et al. found that chemoheterotrophic denitrifying bacteria T.mechernichensis could use organics as carbon sources to reduce $\mathrm{NO}_{3}^{-}$to $\mathrm{N}_{2} \mathrm{O}$ and $\mathrm{N}_{2}$ in an anaerobic 
Table 2. Similar strains according to base comparison.

\begin{tabular}{|c|c|c|c|c|}
\hline No. of Band & Similar strain & Similarity & Login number & Genus \\
\hline $2,3,41,48,63,72,74,79,89,97,114$ & V.modesticaldus & $99.45 \%$ & AM050346 & Vulcanibacillus \\
\hline 6,94 & B.alcalophilus & $98.04 \%$ & X60603 & Bacillus \\
\hline 16 & B.aryabhattai & $99.28 \%$ & EF114313 & \\
\hline $14,19,46,59,66$ & B.luteus & $98.46 \%$ & HE996968 & \\
\hline $7,8,10,37,43,55,71,77,85,87,91,93$ & T.aminoaromatica & $99.98 \%$ & AMXD01000247 & \multirow{5}{*}{ Thanera } \\
\hline $\begin{array}{c}12,21,25,27,35,40,45,53,54,62,69,82,96,99 \\
110,111,112\end{array}$ & T.phenylacetica & $99.98 \%$ & AMXF01000339 & \\
\hline 49 & T.selenatis & $98.37 \%$ & Y17591 & \\
\hline 24,88 & T.mechernichensis & $98.35 \%$ & Y17590 & \\
\hline 109 & T.aromatica & $95.37 \%$ & X77118 & \\
\hline 9,47 & P.solventiborans & $99.18 \%$ & Y07705 & Paracoccus \\
\hline $5,34,67,83,70,104,108$ & A.taiwanensis & $97.12 \%$ & GQ389714 & Azoarcus \\
\hline $26,38,60,68,84,116$ & G.ferrihydriticua & $97.11 \%$ & DQ309326 & Geoalkalibacter \\
\hline
\end{tabular}

Table 3. Characteristics of species for sulfur and nitrogen removal.

\begin{tabular}{|c|c|c|}
\hline Genus & Morphological characteristics & Trophic mode \\
\hline Vulcanibacillus & gram-positive bacteria, rod & $\begin{array}{l}\text { strictly anaerobic, chemoheterotrophic, denitrification using } \mathrm{NO}_{3}^{-} \\
\text {as electron acceptor, no fermentation metabolism }\end{array}$ \\
\hline Thanera & gram-negative bacteria, rod & $\begin{array}{l}\text { facultative anaerobic, chemoheterotrophic, denitrification using denitrification } \\
\text { using } \mathrm{NO}_{3}^{-} \text {and } \mathrm{NO}_{2}^{-} \text {as electron acceptors }\end{array}$ \\
\hline Paracoccus & $\begin{array}{l}\text { gram- negative bacteria, } \\
\text { spherical or short rod }\end{array}$ & $\begin{array}{l}\text { facultative anaerobic, chemotrophic heterotrophic or facultative } \\
\text { chemoautotrophic, no fermentation metabolism, denitrification using } \mathrm{NO}_{3}^{-} \\
\text {as electron acceptors }\end{array}$ \\
\hline Azoarcus & $\begin{array}{l}\text { gram-negative, } \\
\text { rod }\end{array}$ & $\begin{array}{l}\text { nitrogen fixation, some strains can denitrify, among which A.taiwanensis } \\
\text { is desulfurization and denitrification bacteria }\end{array}$ \\
\hline
\end{tabular}

environment [25]. $\mathrm{N}_{2} \mathrm{O}$ was found to be further reduced to $\mathrm{N}_{2}$ as well. Therefore, Thauera was the main heterotrophic denitrifying bacteria in this mixotrophic denitrification desulfurization system, which followed the chemical reactions shown in Equations (1) and (2). The five species of Thauera cooperated to reduced $\mathrm{NO}_{3}^{-}$and $\mathrm{NO}_{2}^{-}$to $\mathrm{N}_{2} \mathrm{O}$, and further converted $\mathrm{N}_{2} \mathrm{O}$ to $\mathrm{N}_{2}$, which could be discharged into the atmosphere.

$6 \mathrm{NO}_{3}^{-}+1.25 \mathrm{C}_{6} \mathrm{H}_{12} \mathrm{O}_{6} \rightarrow 3 \mathrm{~N}_{2}+4.5 \mathrm{H}_{2} \mathrm{O}+6 \mathrm{HCO}_{3}^{-}+1.5 \mathrm{CO}_{2}$

$10 \mathrm{NO}_{2}{ }^{-}+1.25 \mathrm{C}_{6} \mathrm{H}_{12} \mathrm{O}_{6} \rightarrow 5 \mathrm{~N}_{2}+5 \mathrm{H}_{2} \mathrm{O}+5 \mathrm{HCO}_{3}{ }^{-}+2.5 \mathrm{CO}_{3}{ }^{2-}$

The P.solventiborans was the only specie of Paracoccus discovered in this system, which was isolated from a sludge bed treating natural gas [26]. It was gram-positive at logarithmic phase, gram-negative at stable growth stage, and facultative anaerobic. Its optimum $\mathrm{pH}$ was 7-8 and its optimum growth temperature was $30-37^{\circ} \mathrm{C}$. Under the anaerobic environment it could utilize organics as carbon sources, and $\mathrm{NO}_{3}{ }^{-}$as the only electron acceptor to generate $\mathrm{N}_{2}$. The growth of P.solventiborans could be promoted if supplied with a low concentration of $\mathrm{S}_{2} \mathrm{O}_{3}{ }^{2-}$, but was inhibited by a high concentration of $\mathrm{S}_{2} \mathrm{O}_{3}{ }^{2}$. It was suspected that P.solventiborans had a relationship with sulfur compound removal, which could later be studied further.

Vulcanibacillus was also the chemoheterotrophic denitrifying bacteria in this bioreactor. It was gram-positive bacteria, rod, and strictly anaerobic. The $\mathrm{NO}_{3}{ }^{-}$was adopted as the only electron acceptor by Vulcanibacillus, and was reduced to $\mathrm{NO}_{2}^{-}$rather than $\mathrm{N}_{2}$. The V.modesticaldus was the only species of Vulcanibacillus in this system, and it was isolated from the deep-sea hydrotherm with growth $\mathrm{pH}$ of 6-8.5 and optimum growth temperature of $37-60^{\circ} \mathrm{C}$ [27]. V.modesticaldus could reduce $\mathrm{NO}_{3}^{-}$to $\mathrm{NO}_{2}^{-}$rather than $\mathrm{N}_{2}$. However, little $\mathrm{NO}_{2}^{-}$was found in the effluent of this bioreactor, even though the influent $\mathrm{NO}_{2}^{-}$concentration was high at160 mgN/L. The removal of an enormous amount of $\mathrm{NO}_{2}^{-}$was discussed as being attributted to the Thauera and Azoarcus mentioned below, because Paracoccus in this system could only accept $\mathrm{NO}_{3}-$ as electron acceptors. 
Azoarcus had the function of nitrogen fixation, among which certain strains had the function of denitrification, such as A.tolulyticus, A.taiwanensis, and A.evansii. In this bioreactor, A.taiwanensis was found to have the function of denitrification desulfurization. A.taiwanensis was isolated from hot springs, which was gram-negative, in rod shape [28]. It could survive in an environment of $15-40^{\circ} \mathrm{C}$ and its optimum growth temperature was $37^{\circ} \mathrm{C}$. It could exist under $\mathrm{pH}$ of 6.5-10.5 and the optimum growth $\mathrm{pH}$ was 9.0. It was facultative anaerobic and chemolithotrophic. A.taiwanensis utilized $\mathrm{S}^{2-}$ as electron donor and $\mathrm{NO}_{3}^{-}$or $\mathrm{NO}_{2}^{-}$as electron acceptors, and finally converted them to $\mathrm{S}$ and $\mathrm{N}_{2}$. Therefore, A.taiwanensis was the main denitrification desulfurization functional bacteria, which followed the chemical reactions shown in Equations (3) and (4).

$$
\begin{gathered}
5 \mathrm{~S}^{2-}+2 \mathrm{NO}_{3}{ }^{-}+12 \mathrm{H}^{+} \rightarrow 5 \mathrm{~S}+\mathrm{N}_{2}+6 \mathrm{H}_{2} \mathrm{O} \\
3 \mathrm{~S}^{2-}+2 \mathrm{NO}_{2}{ }^{-}+8 \mathrm{H}^{+} \rightarrow 3 \mathrm{~S}+\mathrm{N}_{2}+4 \mathrm{H}_{2} \mathrm{O}
\end{gathered}
$$

In addition, the alkaliphile Geoalkalibacter and Bacillus exsited in this system, which was discussed to be the reason for maintaining the stable alkalinity in this complicated environment. According to Fig. 3, the effluent $\mathrm{pH}$ was higher than the influent $\mathrm{pH}$ and was stable. It was analyzed that the alkaliphile existing in this system stabilized the alkalinity.

\section{Conclusions}

The upflow attached-growth bioreactor actualized simultaneous removal of $\mathrm{S}^{2-}, \mathrm{NO}_{3}^{-}, \mathrm{NO}_{2}^{-}$, and organics using the mixotrophic denitrification desulfurization process. The microorganisms in this system were collected to study microbial community characteristics. Both sulfur-based denitrification and heterotrophic denitrification were considered to exist in the bioreactor. Thauera, Paracoccus, and Vulcanibacillus were the main heterotrophic denitrifying bacteria. Thauera and Paracoccus could use $\mathrm{NO}_{3}^{-}$and $\mathrm{NO}_{2}^{-}$as electron acceptors, while Vulcanibacillus could only convert $\mathrm{NO}_{3}^{-}$to $\mathrm{NO}_{2}^{-}$. The generating $\mathrm{NO}_{2}^{-}$was presumed to be further removed by Thauera, Paracoccus, and Azoarcus. Azoarcus was the main sulfur-based denitrification bacteria in this system, which utilized $\mathrm{S}^{2-}$ as an electron donor and $\mathrm{NO}_{3}{ }_{3}^{-}$or $\mathrm{NO}_{2}^{-}$ as electron acceptors. The sulfurous and nitrogenous compounds were finally converted to $\mathrm{S}$ and $\mathrm{N}_{2}$, which would not lead to secondary pollution.

\section{Acknowledgements}

The authors wish to thank the National Natural Science Foundation of China (51208070), the Foundation of the Liaoning Education Department (L2014201), and the Fundamental Research Funds for the Central Universities of China (3132014102, 3132015083).
This work was supported in part by a grant from these funds.

\section{References}

1. YANG Z.Q., ZHOU S.Q., SUN Y.B. Start-up of simultaneous removal of ammonium and sulfate from an anaerobic ammonium oxidation (anammox) process in an anaerobic upflow bioreactor. J. Hazard. Mater. 169 (1-3), 113, 2009.

2. SAPEK A. Magnitude of nitrogen and phosphorus delivered to Baltic Sea via Polish rivers. Pol. J. Environ. Stud. 23 (6), 2191, 2014.

3. CAMILOTI P.R., MACKAITIS G., RODRIGUES J.A.D., DAMIANOVIC M.H. R.Z., FORESTI E., ZAIAT M. Innovative anaerobic bioreactor with fixed-structured bed (ABFSB) for simultaneous sulfate reduction and organic matter removal. J. Chem. Technol. Biot. 89 (7), 1044, 2014.

4. ZHANG T., WU C., LIU Y., ZHOU X., WANG T.A., SHI $\mathrm{H}$. Study on the influence of oxygen aeration as a means of controlling sulfide accumulation of sewer system. China Environ. Sci. 33 (1), 1953, 2013.

5. REYES-AVILA J.S., RAZO-FLORES E., GOMEZ L. Simultaneous biological removal of nitrogen, carbon and sulfur by denitrification. Water Res. 38 (14-15), 3313, 2004.

6. DOWNS T.J., CIFUENTES-GARCIA E., IRWIN MEL SUFFET. Risk screening for exposure to groundwater pollution in a wastewater irrigation district of the Mexico City region. Environ. Health Perspect. 107 (7), 553, 1999.

7. BAKER L.A. Design considerations and application for wetland treatment of high-nitrate waters. Water Sci. Technol. 38 (1), 389, 1998.

8. DRISCOLL C.T, BISOGNI J.J. Use of sulfur and sulfide in packed-bed reactors for autotrophic denitrification. J. Wat. Pollut. Control Federation. 50, 569, 1978.

9. KRISHNAKUMAR B., MANILAL V.B. Bacterial oxidation of sulfide under denitrifying conditions. Biotechnol. Lett. 21, 437, 1999.

10. LIU C., ZHAO C., WANG A., GUO Y., LEE DUU-JONG Denitrifying sulfide removal process on high-salinity wastewaters. Appl. Microbiol. Biotechnol. 99, 6463, 2015.

11. LI R., FENG C., HU W., XI B., CHEN N., ZHAO B., LIU Y., HAO C., PU J. Woodchip-sulfur based heterotrophic and autotrophic denitrification (WSHAD) process for nitrate contaminated water remediation. Water Res. 89, 171, 2016.

12. KIMBERLEY T., SHIJIE A., MEHDI N. Evaluation of autotrophic and heterotrophic processes in biofilm reactors used for removal of sulphide, nitrate and COD. Bioresour. Technol. 101, 8109, 2010.

13. CAI J., ZHENG P., HU B. L., JIN R., JIANG J. Influence of $\mathrm{pH}$ and alkalinity on process performance of simultaneous anaerobic sulfide and nitrate removal. Journal of Chemical Industry and Engineering (China). 59 (5), 1264, 2008.

14. CHEN Z.A. Screening, isolation and identification of simultaneous denitrification desulfurization strains. China Biogas. 26 (6), 3, 12, 2008.

15. GEVERTZ D., TELANG A.J., VOORDOUW G., JENNEMAN G.E. Isolation and characterization of strains CVO and FWKOB, two novel nitrate-reducing,sulfideoxidizing bacteria isolated from oil field brine. Appl. Environ. Microbiol. 66, 2491, 2000.

16. CHEN Z., CHEN H., WEI B., LIU G., DENG L., WU L. Effects of the ratio of $\mathrm{NO}_{3}^{-}-\mathrm{N}$ to $\mathrm{NO}_{2}^{-}-\mathrm{N}$ on the removal of sulfide and nitrogen by mixed culture and pure culture. Environ. Sci. 35 (2), 746, 2014. 
17. WANG L., WEI B., CHEN Z., DENG L., SONG L., WANG S., ZHENG D., LIU Y., PU X., ZHANG Y. Effect of inoculum and sulfide type on simultaneous hydrogen sulfide removal from biogas and nitrogen removal from swine slurry and microbial mechanism. Appl. Environ. Microbiol. 99, 10793, 2015.

18. JANSSEN A., DEKEIZER A., VANAELST A., FOKKINK R., YANGLING H. LETTINGA G. Surface characteristics and aggregation of microbiologically produced sulphur particles in relation to the process conditions. Colloids Surf. B. 6 (2), 115, 1996.

19. RENA Y.G., WANG J.H., LI H.F. ZHANG J., QI P.Y., HU Z., Nitrous oxide and methane emissions from different treatment processes in full-scale municipal wastewater treatment plants. Environ. Technol. 34 (21-24), 2917, 2013.

20. APHA. Standard Methods for the Examination of Water and Wastewater 21stedn, American Public Health Association/ American Water Works Association/Water Environment Federation, Washington DC, USA, 2005.

21. HENSHAW P.F., BEWTRA J.K. BISWAS N. Extraction of elemental sulfur from aqueous suspension- for analysis by high-performance liquid chromatography. Anal. Chem. 69, 3119, 1997.

22. MECHICHI T., STACKEBRANDT E., GAD'ON N, FUCHS, G. Phylogenetic and metabolic diversity of bacteria degrading aromatic compounds under denitrifying conditions, and description of Thauera phenylacetica sp nov., Thauera aminoaromatica sp nov., and Azoarcus buckelii sp nov. Arch. Microbiol. 178 (1), 26, 2002.

23. CANTAFIO A.W., HAGEN K.D., LEWIS G.E., BLEDSOE, T.L., NUNAN K.M., MACY J.M. Pilot-scale selenium bioremediation of San Joaquin drainage water with Thauera selenatis. Appl. Environ. Microbiol. 62, 298, 1996.
24. ANDERS H.J., KAETZKE A., KÄMPFER P., LUDWIG W., FUCHS G. Taxonomic position of aromatic-degrading denitrifying pseudomonad strains K 172 and KB 740 and their description as new members of the genera Thauera, as Thauera Aromatica sp. nov., and Azoarcus, as Azoarcus Evansii sp. nov., respectively, members of the beta subclass of the Proteobacteria. Int. J. Syst. Bacteriol. 452, 327, 1995.

25. SCHOLTEN E., LUKOW T. AULING G., KROPPENSTEDT R.M., RAINEY F.A., DIEKMANN H. Thauera Mechernichensis sp. nov., an aerobic denitrifier from a leachate treatment plant. Int. J. Syst. Bacteriol. 49 (3), 1045, 1999.

26. SILLER H., RAINEY F.A., STACKEBRANDT E., WINTER J. Isolation and characterization of a new gramnegative, acetone-degrading, nitrate-reducing bacterium from soil, Paracoccus solventivorans sp. nov. Int. J. Syst. Bacteriol. 464, 1125, 1996.

27. L'HARIDON S., MIROSHNICHENKO M.L., KOSTRIKINA N.A., TINDALL B.J., SPRING S., SCHUMANN P., STACKEBRANDT E., BONCHOSMOLOVSKAYA E.A., JEANTHON C. Vulcanibacillus modesticaldus gen. nov., sp. nov., a strictly anaerobic, nitratereducing bacterium from deep-sea hydrothermal vents. Int. J. Syst. Evol. Micr. 56, 5, 047, 2006.

28. LEE DUU-JONG, WONG BIING-TEO, ADAV SUNIL S. Azoarcus Taiwanensis sp. nov., a denitrifying species isolated from a hot spring. Appl. Microbiol. Biotechnol. 983, 1301, 2014. 